\title{
China's counterfeit medicine trade booming
}

Published at www.cmaj.ca on Oct. 5.

I $\mathrm{t}$ was a cringe-worthy moment for China when 600000 counterfeit antimalarial tablets were intercepted by the Nigerian government in June. Produced and shipped from China, they bore an unexpected label: "Made in India." Even the fakes were being faked. It was a new low.

Many things are faked in China from Gucci sunglasses to iPhones. Drugs are no exception. Medicine counterfeiters in China have the dubious honour of being among the worst offenders in the counterfeit drug trade. Often stuffed with chalk, flour or pollen, the pills are passed off as genuine medications. The drug counterfeiters are so skilled that even the holograms on the packages are copied and faked. It's a trade that preys upon poorer countries, such as Nigeria, that lack the funds to set up strict regulation and the ability to purchase higher-quality drugs.

"China, along with India, is responsible for the vast majority of the fakes making it to the international market," says Roger Bate, an economist who researches health policy and author of Making a Killing: The Deadly Implications of the Counterfeit Drug Trade.

In a fluid worldwide market, it is extremely difficult to catch drug counterfeiters as their channels to get fake drugs into a given country often have stops in several other nations first. From China, many of the fake medicines move west, often passing through the Middle East and Europe. It is a difficult route to track. Intelligence reports say fake medicines can change hands more than 30 times before reaching buyers.

Many people within China are wary of using pharmaceuticals because so many drugs are thought to be fake. Yu Nan, a 23-year-old teacher, says his experiences make him believe many of the drugs sold in local pharmacies are fakes. In 2006, he was diagnosed with a kidney infection and was given antibi-

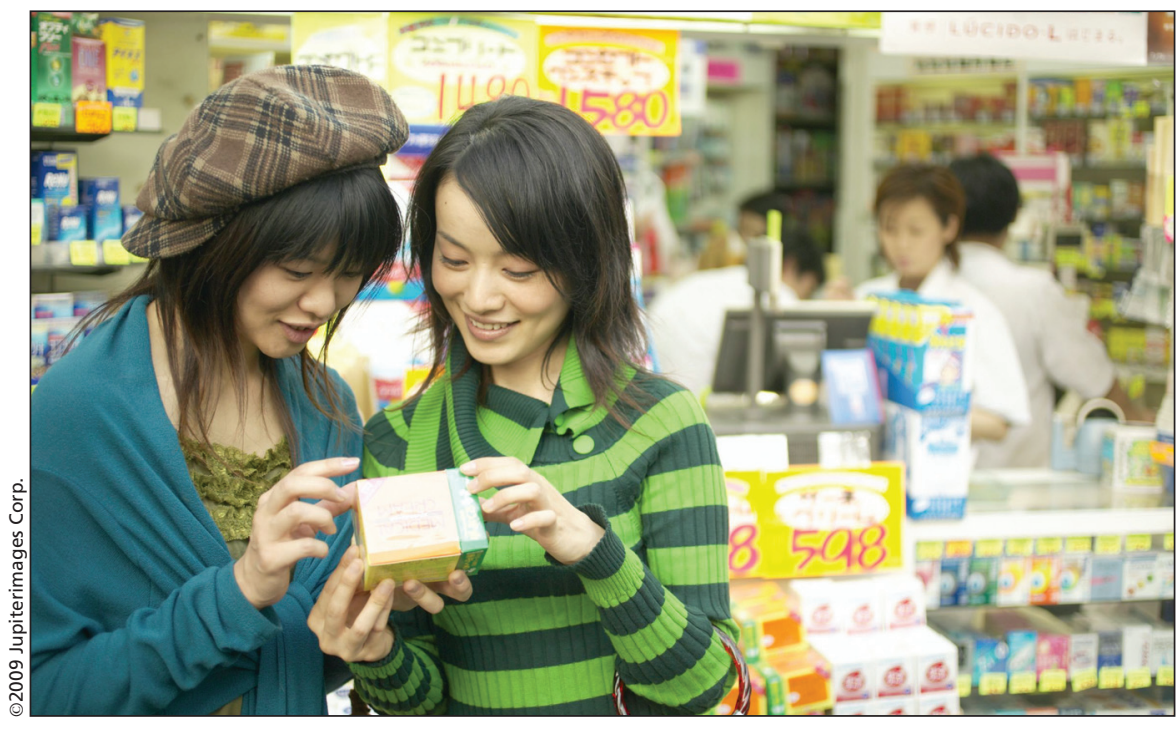

Shoppers at pharmacies in China may think they are buying legitimate medicine, but in some cases they are purchasing little more than tablets of chalk, flour or pollen.

otics. As the days went on, his infection grew worse and worse despite taking the pills. After day 9, he went back to the doctor and was told the pills could be fake.

"I don't trust the drugs in the shops here," he says. "The drugs didn't work. They were empty, a waste. And I suffered because of it."

Fake drugs, however, are difficult to detect in a country with little regulation. People caught making fake drugs usually face paltry fines - between 100 RMB (\$17) and 3000 RMB (\$507). However, above and beyond fines, they can also face the death penalty. It was used in China in 2007 when the head of the State Food and Drug Administration was executed over his involvement in a licensing scandal.

Last year Chinese suppliers were blamed for the contamination of heparin in the United States after reports of deaths (as many as 81) and hundreds of allergic reactions. In January, a diabetes drug was pulled after samples showed the medicine, which killed two people in the western region of Xinjiang, was six times as potent as it should have been.

In China, according to Bate, there is a small amount of evidence that links the People's Liberation Army [PLA] to the counterfeit drug trade, although nothing has been proven. "We do know that PLA hospitals have sold lots of fake drugs. This makes the government's job difficult as they have little de facto control over the PLA so major producers are not going to be stopped," he adds.

Other countries, however, have successfully cracked down on drug counterfeiters. Perhaps most notable is Nigeria, which was previously one of the countries hardest hit by drug counterfeiters. In 2001, an estimated half of the drugs in the country - from antibiotics to antimalarials - were fake. At the time, the head of Nigeria's National Agency for Food and Drug Administration and Control (NAFDAC), Dr. Dora Akunyili, was at the forefront of the fight against the drug counterfeiters after her sister Vivian died after injecting fake insulin in 1988 .

"Drug counterfeiting is mass murder," says Akunyili. "It is one of the greatest atrocities of our time. It is a form of terrorism against public health as well as an act of economic sabotage." 
During Akunyili's posting at NAFDAC, which ran until 2008, the percentage of drugs on the market that were counterfeit dropped from $50 \%$ to about $15 \%$. More than 50 drug counterfeiters were convicted under counterfeit legislation, and thousands of fake medications were burned and destroyed. Her activities did not make her popular with drug counterfeiters, who wanted to get even with the woman who stepped on their toes, shut down their factories and stopped their fake pills from killing innocent people.

In fact, they wanted her dead. In 2003, they attempted to assassinate her while she was in her car. But Akunyili survived the attack and continued her quest to stop the flow of fake drugs into
Nigeria. One obstacle in her quest, she says, is that drug companies are somewhat quiet about publicizing the issue of counterfeit drugs for fear their stock prices will drop. "When we first started creating awareness about fake drugs in Nigeria in 2001, the drug companies were not happy because they felt that it could damage legitimate business."

Back in China, a surprising acknowledgment was made about the fake drugs intercepted in Nigeria with the label "Made in India."

At a press conference, Cui Enxue, director of China's State Food and Drug Administration drug safety inspection bureau, said overseas pharmacies should only deal with registered Chinese drug producers.
"We'll investigate the case thoroughly and refer any Chinese drug companies involved to the law-enforcement and justice department if they are found to have broken the law," said Cui.

At the same time, new fake drugs are popping up in China - this time, falsely claiming to cure pandemic (H1N1) 2009. Despite pleas and promises for a crackdown on drug counterfeiters, there is a bigger question about what response is needed from the Chinese government to stop the flow of fake drugs from the country, and what, if anything, will be done by Beijing to improve the current situation. - Katie Lewis, Beijing, China

DOI:10.1503/cmaj.109-3070 